\title{
Study on Pathogenicity Test of Meloidogyne incognita on Different Vegetable Crops
}

\author{
Anamika \\ ${ }^{1}$ Department of Agriculture, CAFF, FNU, Fiji \\ Correspondence: Anamika, Department of Agriculture, CAFF, FNU, Fiji. E-mail: \\ anamika_bhu01@rediffmail.com
}

Received: August 25, 2014 Accepted: January 3, 2015 Online Published: February 15, 2015

doi:10.5539/jas.v7n3p105 URL: http://dx.doi.org/10.5539/jas.v7n3p105

\begin{abstract}
The relationships between the population density of Meloidogyne incognita and damage to test crop have been investigated. Symptoms were more pronounced of damage with ageing of the crop, but indicative only at population levels above that initiated damage. The nature and extent of damage caused by root-knot nematodes, M. incognita to test crop at different inoculum levels of 500, 1000, 2000 and 3,000 larvae per plant was studied, in pot culture. The influence of four initial inoculum densities of root-knot nematode, Meloidogyne incognita and plant age on root-knot disease of test crop shows significant reduction in the plant growth parameters and increase of initial inoculum densities increase in root-knots there by increasing nematode population but this increase was inversely proportional with the nematode population which was density dependent which causes competition for nutrition among the developing nematodes within available root system and also due to inability of juveniles of subsequent generation to find infection sites.
\end{abstract}

Keywords: test crop (tomato, brinjal, spinach, and beet root), Meloidogyne incognita, pathogenicity

\section{Introduction}

Plant parasitic nematodes are generally regarded as silent enemies, losses of up to $80 \%$ have been associated with them in vegetable fields that are heavily infested (Anamika et al., 2011; Siddiqi, 2000; Kaskavalci, 2007). About 2000 plants are susceptible to their infection and they cause approximately $5 \%$ of global crop loss (Hussey \& Janssen, 2002). They cause high level of economic loss in agricultural crops worldwide. They are capable of severely damaging a wide range of crops, in particular vegetable causing dramatic yield losses mainly in tropical and subtropical agriculture (Sikora \& Fernandez, 2005). The Root-knot nematodes destroy 29-90 percent of vegetable crops annually.

Root-knot nematode damage results in poor growth, a decline in quality and yield of the crop and reduced resistance to other stresses (e.g. drought, other diseases). A high level of root-knot nematode damage can lead to total crop loss. The infection starts when infective second-stage juveniles $\left(\mathrm{J}_{2}\right)$ hatch from eggs in the soil and penetrate plant roots behind the root cap and migrate intercellularly in the cortical tissue to the vascular cylinder and then become sedentary. Then they inject secretions into five to seven undifferentiated procambial cells in the vascular cylinder near the head of the $\mathbf{J} 2$ to become multi-nucleate (Hussey \& Grundler, 1998) and to form very specialized feeding cells called giant cells, on which the juveniles $\left(\mathrm{J}_{2}\right)$ and later the spherical females feed (Sijmons et al., 1994). Furthermore, cell size increases dramatically, walls are remodelled by formation of ingrowths and the cytoplasm becomes dense with an increase in cell organelles (Baum et al., 1996). With nourishment from the giant-cells, the root-knot nematodes complete their life cycle. Then females lay eggs into a gelatinous matrix outside the roots surfaces. The infection of the root systems by phytoparasitic nematodes of the genus Meloidogyne is easily recognized by one formation of galls. These galls descend from the development of the giant cells and the females inside the roots. Nematode damaged roots do not utilise water and fertilisers effectively, leading to additional losses. Infection of young plants may be lethal, while infection of mature plants causes decreased yield. Meloidogyne species constitute the major nematode problem in developing countries.

\section{Materials and Methods}

\subsection{Pathogenicity}

Pathogenicity gives conclusive evidence of the destructive potential of the parasite. The basic information 
regarding the pathogenic behavior of $M$. incognita on major vegetable crops is of utmost importance for the management of root knot disease. Although a lot of information is already available on these aspects regarding to Meloidogyne species affecting a large number of economically important vegetable crops, adequate and useful information is still lacking. The present study was conducted to find out the pathogenic abilities at different inoculum levels of root knot nematode on the test crop. For testing the effect of different level of inoculums of $M$. incognita on the test crops (Tomato, Brinjal, Spinach and Beet root) autoclaved soil was filled in pots of $20 \mathrm{~cm}$. diameter and in the centre five seeds of each crop were sown. After 15 days of their sowing only one seedling per pot was allowed to grow. When the seedlings were 20 days old, these pots were inoculated with infective stages of nematode (collected from the stock culture, maintained on okra plant in glass house) using five different inoculum levels, viz.

T0: control (without nematode)

T1: 500 larvae/ pot

T2: 1000 larvae/ pot

T3: 2000 larvae/ pot

T4: 3000 larvae/ pot

Each treatment was replicated four times and the pots were placed in net house in a randomized design and irrigated as and when required. The experiment was terminated after 90 days after inoculation (DAI) and the data were analyzed statistically. Observation regarding plants attributes and nematode population were recorded as follows:

Shoot and Root length (cm), Fresh shoot and root weight (g), Number of knots per plants (root knot index), Total number of nematode population per pot and Reproduction factor $(\mathrm{RF}=\mathrm{Pf} / \mathrm{Pi})$ where $\mathrm{Pi}=$ Initial population, $\mathrm{Pf}=$ Final population.

For total number of nematode population, the plant roots were washed thoroughly under a gentle stress of water and soil was washed by modified Cobb's sieving and decanting method followed by modified Baermann's funnel method (Southey, 1986). The rate of reproduction factor was calculated from total nematode population (root + soil) in relation to the initial inoculum levels. The root-knot index was measured on visual observation of the root system as given below (Mishra \& Prasad, 1974):

Table 1. Root-knot index

\begin{tabular}{lll}
\hline Number of knots per plant & Index & Remarks \\
\hline 0 & 1 & No galling \\
$0-50$ & 2 & Light galling \\
$51-100$ & 3 & Slight galling \\
$101-200$ & 4 & Moderate galling \\
More than 200 & 5 & Heavy galling \\
\hline
\end{tabular}

\section{Results and Discussion}

\subsection{Pathogenicity}

The findings of test of pathogenicity in the Table 2 to 5 (Figure 1) reveals that increase in nematode inoculums was associated with progressive reduction in plant growth parameters of all the test crops which gave conclusive evidence that $M$. incognita is potential pathogens for these crops. The rate of multiplication was inversely proportional to the population density. An increase in level of inoculum resulted in increase in root-knots there by increasing nematode population but this increase was inversely proportional with the nematode population which was density dependent which causes competition for nutrition among the developing nematodes within available root system and also due to inability of juveniles of subsequent generation to find infection sites. 
Table 2. Effect of different inoculums level of $M$. incognita on tomato

\begin{tabular}{|c|c|c|c|c|c|c|c|c|c|c|}
\hline \multirow[b]{2}{*}{ Treatments } & \multirow{2}{*}{$\begin{array}{l}\text { Shoot } \\
\text { length } \\
(\mathrm{cm})\end{array}$} & \multirow{2}{*}{$\begin{array}{l}\text { Shoot } \\
\text { weight } \\
\text { (g) }\end{array}$} & \multirow{2}{*}{$\begin{array}{l}\text { Root } \\
\text { length } \\
(\mathrm{cm})\end{array}$} & \multirow{2}{*}{$\begin{array}{l}\text { Root } \\
\text { weight } \\
\text { (g) }\end{array}$} & \multirow{2}{*}{$\begin{array}{l}\text { No. of } \\
\text { knots/ } \\
\text { plant }\end{array}$} & \multirow{2}{*}{$\begin{array}{l}\text { Root } \\
\text { Knot } \\
\text { Index }\end{array}$} & \multicolumn{3}{|c|}{ Final Population/pot } & \multirow[b]{2}{*}{$\mathrm{RF}$} \\
\hline & & & & & & & Soil & Root & Total & \\
\hline $\mathrm{T}_{0}$ (control) & 29.5 & 14.5 & 18.3 & 5.7 & 0 & 1 & 0 & 0 & 0 & 0 \\
\hline $\mathrm{T}_{1}\left(500 \mathrm{~J}_{2}\right)$ & 27.7 & 13.8 & 14.9 & 4.8 & 29.5 & 2 & 467.4 & 731.4 & 1198.8 & 2.3 \\
\hline $\mathrm{T}_{2}\left(1000 \mathrm{~J}_{2}\right)$ & 24.1 & 12.3 & 15.0 & 4.7 & 71.2 & 3 & 553.6 & 816.6 & 1370.2 & 1.3 \\
\hline $\mathrm{T}_{3}\left(2000 \mathrm{~J}_{2}\right)$ & 22.3 & 10.0 & 13.5 & 4.3 & 92.0 & 3 & 712.2 & 936.2 & 1648.4 & 0.8 \\
\hline $\mathrm{T}_{4}\left(3000 \mathrm{~J}_{2}\right)$ & 18.5 & 8.6 & 10.3 & 3.1 & 112.0 & 4 & 798.3 & 1138.4 & 1930.7 & 0.64 \\
\hline F-test & $\mathrm{S}$ & $\mathrm{S}$ & $\mathrm{S}$ & $\mathrm{S}$ & $\mathrm{S}$ & $\mathrm{S}$ & & $\mathrm{S}$ & & $\mathrm{S}$ \\
\hline CD@5\% & 0.58 & 0.63 & 0.39 & 0.47 & 0.3 & 0.3 & & 0.4 & & 0.13 \\
\hline
\end{tabular}

Table 3. Effect of different inoculums level of M. incognita on Brinjal

\begin{tabular}{|c|c|c|c|c|c|c|c|c|c|c|}
\hline \multirow{2}{*}{ Treatments } & \multirow{2}{*}{$\begin{array}{l}\text { Shoot } \\
\text { length } \\
(\mathrm{cm})\end{array}$} & \multirow{2}{*}{$\begin{array}{l}\text { Shoot } \\
\text { weight } \\
\text { (g) }\end{array}$} & \multirow{2}{*}{$\begin{array}{l}\text { Root } \\
\text { length } \\
(\mathrm{cm})\end{array}$} & \multirow{2}{*}{$\begin{array}{l}\text { Root } \\
\text { weight } \\
\text { (g) }\end{array}$} & \multirow{2}{*}{$\begin{array}{l}\text { No. of } \\
\text { knots/ } \\
\text { plant }\end{array}$} & \multirow{2}{*}{$\begin{array}{l}\text { Root } \\
\text { Knot } \\
\text { Index }\end{array}$} & \multicolumn{3}{|c|}{ Final Population/pot } & \multirow{2}{*}{$\mathrm{RF}$} \\
\hline & & & & & & & Soil & Root & Total & \\
\hline $\mathrm{T}_{0}$ (control) & 19.75 & 3.74 & 18.1 & 1.67 & 0 & 1 & 0 & 0 & 0 & 0 \\
\hline $\mathrm{T}_{1}\left(500 \mathrm{~J}_{2}\right)$ & 19.1 & 3.48 & 16.8 & 1.42 & 44.8 & 2 & 486.2 & 755.4 & 1241.6 & 2.48 \\
\hline $\mathrm{T}_{2}\left(1000 \mathrm{~J}_{2}\right)$ & 18.1 & 2.9 & 13.5 & 1.9 & 81.5 & 3 & 581.8 & 921.2 & 1503.0 & 1.50 \\
\hline $\mathrm{T}_{3}\left(2000 \mathrm{~J}_{2}\right)$ & 14.5 & 2.24 & 11.78 & 2.45 & 112.2 & 4 & 821.4 & 989.4 & 1810.8 & 0.91 \\
\hline $\mathrm{T}_{4}\left(3000 \mathrm{~J}_{2}\right)$ & 12.53 & 1.61 & 9.5 & 2.99 & 181.5 & 4 & 885.8 & 1248.2 & 2134.0 & 0.71 \\
\hline F-test & $\mathrm{S}$ & $\mathrm{S}$ & $\mathrm{S}$ & $\mathrm{S}$ & $\mathrm{S}$ & $\mathrm{S}$ & & $\mathrm{S}$ & & S \\
\hline $\mathrm{CD}$ at $5 \%$ & 0.37 & 0.56 & 0.3 & 0.52 & 0.334 & 1.06 & & 0.21 & & 0.43 \\
\hline
\end{tabular}

Table 4. Effect of different inoculums level of M. incognita on Spinach

\begin{tabular}{|c|c|c|c|c|c|c|c|c|c|c|}
\hline \multirow[b]{2}{*}{ Treatments } & \multirow{2}{*}{$\begin{array}{l}\text { Plant } \\
\text { weight } \\
\text { (g) }\end{array}$} & \multirow{2}{*}{$\begin{array}{l}\text { No. of } \\
\text { leaves }\end{array}$} & \multirow{2}{*}{$\begin{array}{l}\text { Length of } \\
\text { petiole } \\
(\mathrm{cm})\end{array}$} & \multirow{2}{*}{$\begin{array}{l}\text { Width of } \\
\text { lamina } \\
(\mathrm{cm})\end{array}$} & \multirow{2}{*}{$\begin{array}{l}\text { No. of } \\
\text { knots/ } \\
\text { plant }\end{array}$} & \multirow{2}{*}{$\begin{array}{l}\text { Root } \\
\text { Knot } \\
\text { Index }\end{array}$} & \multicolumn{3}{|c|}{ Final Population/pot } & \multirow[b]{2}{*}{$\mathrm{RF}$} \\
\hline & & & & & & & Soil & Root & Total & \\
\hline $\mathrm{T}_{0}$ (control) & 27.6 & 17.5 & 7.2 & 6.2 & 0 & 1 & 0 & 0 & 0 & 0 \\
\hline $\mathrm{T}_{1}\left(500 \mathrm{~J}_{2}\right)$ & 25.1 & 15.2 & 9.9 & 5.8 & 25.1 & 2 & 241.4 & 344.6 & 586.0 & 1.2 \\
\hline $\mathrm{T}_{2}\left(1000 \mathrm{~J}_{2}\right)$ & 24.5 & 13.0 & 12.6 & 4.9 & 63.8 & 3 & 464.2 & 618.2 & 1082.4 & 1.08 \\
\hline $\mathrm{T}_{3}\left(2000 \mathrm{~J}_{2}\right)$ & 21.9 & 12.2 & 14.4 & 2.6 & 86.2 & 3 & 531.6 & 816.4 & 1347.4 & 0.67 \\
\hline $\mathrm{T}_{4}\left(3000 \mathrm{~J}_{2}\right)$ & 13.0 & 5.1 & 16.2 & 1.9 & 135.4 & 4 & 699.5 & 912.2 & 1611.7 & 0.53 \\
\hline F-test & $\mathrm{S}$ & S & $\mathrm{S}$ & $\mathrm{S}$ & $\mathrm{S}$ & $\mathrm{S}$ & & S & & $\mathrm{S}$ \\
\hline $\mathrm{CD}$ at $5 \%$ & 2.06 & 0.37 & 0.15 & 0.75 & 0.13 & 0.06 & & 0.34 & & 0.32 \\
\hline
\end{tabular}


Table 5. Effect of different inoculums level of $M$. incognita on Beet-root

\begin{tabular}{|c|c|c|c|c|c|c|c|c|}
\hline \multirow{2}{*}{ Treatments } & \multirow{2}{*}{$\begin{array}{l}\text { Total Root } \\
\text { weight (g) }\end{array}$} & \multirow{2}{*}{$\begin{array}{l}\text { Actual root } \\
\text { weight }(\mathrm{g})\end{array}$} & \multirow{2}{*}{$\begin{array}{l}\text { No. of } \\
\text { knots/plant }\end{array}$} & \multirow{2}{*}{$\begin{array}{l}\text { Root Knot } \\
\text { Index }\end{array}$} & \multicolumn{3}{|c|}{ Final Population/pot } & \multirow{2}{*}{$\mathrm{RF}$} \\
\hline & & & & & Soil & Root & Total & \\
\hline $\mathrm{T}_{0}$ (control) & 27.2 & 26.1 & 0 & 1 & 0 & 0 & 0 & 0 \\
\hline $\mathrm{T}_{1}\left(500 \mathrm{~J}_{2}\right)$ & 29.5 & 25.3 & 38.4 & 2 & 375.2 & 632.4 & 1007.6 & 2.01 \\
\hline $\mathrm{T}_{2}\left(1000 \mathrm{~J}_{2}\right)$ & 35.9 & 22.5 & 83.6 & 3 & 484.5 & 893.6 & 1378.1 & 1.37 \\
\hline $\mathrm{T}_{3}\left(2000 \mathrm{~J}_{2}\right)$ & 36.7 & 20.8 & 156.8 & 4 & 553.2 & 974.5 & 1527.7 & 0.76 \\
\hline $\mathrm{T}_{4}\left(3000 \mathrm{~J}_{2}\right)$ & 42.8 & 16.5 & 189.2 & 4 & 688.2 & 1151.2 & 1839.4 & 0.61 \\
\hline F-test & $\mathrm{S}$ & $\mathrm{S}$ & S & S & & S & & S \\
\hline $\mathrm{CD}$ at $5 \%$ & 5.97 & 0.262 & 0.34 & 0.21 & & 0.13 & & 0.37 \\
\hline
\end{tabular}
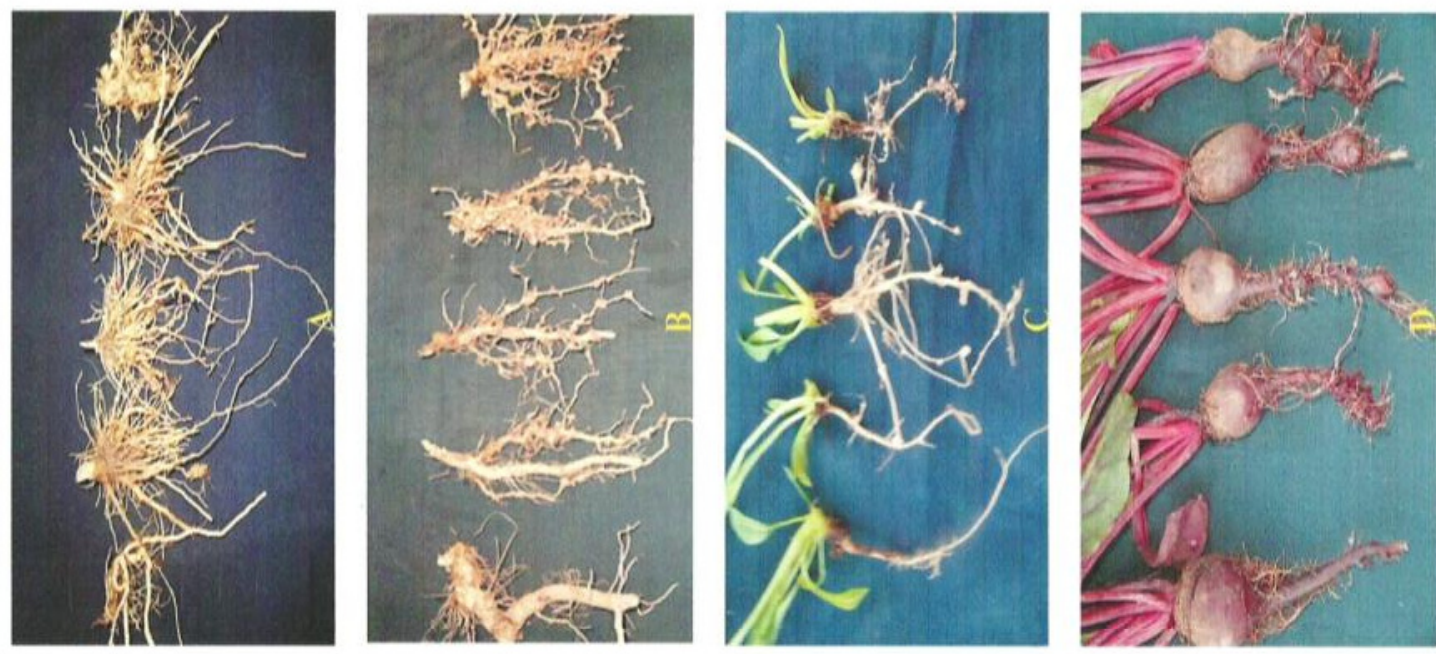

Figure 1. Effect of different inoculum level of $M$. incognita on test crop

\subsection{Tomato}

Data recorded in the Table 2 (Figure 1A) reveals that shoot length and shoot weight was significantly reduced over control. The root length also reduces significantly in all the inoculation pots as compared with uninoculated $\left(\mathrm{T}_{0}\right.$, control). But among the treatments, root length of inoculum level of $500 \mathrm{~J}_{2} /$ pot $\left(\mathrm{T}_{1}, 14.9 \mathrm{~cm}\right)$ and $1000 \mathrm{~J}_{2}$ /pot $\left(\mathrm{T}_{2}, 15.0 \mathrm{~cm}\right)$ was found non-significant. Root weight was also reduced significantly over control but $\mathrm{T}_{1}(4.8$ $\mathrm{g}), \mathrm{T}_{2}(4.7 \mathrm{~g})$ and $\mathrm{T}_{3}(4.3 \mathrm{~g})$ was found non-significant among themselves. The number of root knots and root-knot index was significantly increased but there was no significant difference in root-knot index in $T_{2}$ and $\mathrm{T}_{3}$ treatments. Total nematode population was also increased from $1198.8\left(\mathrm{~T}_{1}\right)$ to $1930.7\left(\mathrm{~T}_{4}\right)$ but rate of reproduction was significantly reduced from $2.3\left(\mathrm{~T}_{1}\right)$ to $0.64\left(\mathrm{~T}_{4}\right)$ respectively (Figure 1A).

\subsection{Brinjal}

Table 3 (Figure 1B) shows the significant reduction in plant growth parameters except root weight. In shoot weight there was non-significant difference among the treatments $\mathrm{T}_{0}$ (control) and $\mathrm{T}_{1}\left(500 \mathrm{~J}_{2} / \mathrm{kg}\right.$ soil). The root weight was reduced $(1.42 \mathrm{~g})$ at minimum population level $\left(\mathrm{T}_{1}, 500 \mathrm{~J}_{2} / \mathrm{kg}\right.$ soil) in comparison to control $\left(\mathrm{T}_{0}, 1.67\right.$ g) but suddenly there was significant increase in root weight with increase in population level from $1.9 \mathrm{gm}\left(\mathrm{T}_{2}\right.$, $1000 \mathrm{~J}_{2} / \mathrm{kg}$ soil) to $2.99 \mathrm{~g}\left(\mathrm{~T}_{4}, 3000 \mathrm{~J}_{2} / \mathrm{kg}\right.$ soil) but no significant difference between $\mathrm{T}_{2}, \mathrm{~T}_{0}$ and $\mathrm{T}_{1}$. This increase was due to formation of heavy galls/knots. Though an increase in the level of inoculum resulted in increased root galling and nematode population. Rate of multiplication was significantly reduced from $2.48\left(\mathrm{~T}_{1}\right)$ to 0.71 ( $\left.\mathrm{T}_{4}\right)$ but found no significant difference among the treatments $\mathrm{T}_{3}\left(2000 \mathrm{~J}_{2} / \mathrm{kg}\right.$ soil $)$ and $\mathrm{T}_{4}\left(3000 \mathrm{~J}_{2} / \mathrm{kg}\right.$ soil $)$ (Figure 1B).

\subsection{Spinach}

Table 4 (Figure 1C) shows that there was significant loss in plant weight as well as quality of leaf with 
decreasing the size and number of leaves. Plant weight at $\mathrm{T}_{0}(27.6 \mathrm{gm})$ significantly reduces to $13.0 \mathrm{gm}$ at highest population level $\left(\mathrm{T}_{4} 3000 \mathrm{~J}_{2} / \mathrm{kg}\right.$ soil). The number of leaves was significantly reduced from $17.5\left(\mathrm{~T}_{0}\right)$ to $5.1\left(\mathrm{~T}_{4}\right)$. The foliage of the heavily infected plants at maximum population level $\left(3000 \mathrm{~J}_{2} / \mathrm{kg}\right.$ soil) was observed to have changed morphologically from its normal structure to lanceolate lamina and longer and upright petioles. The length of petiole increases significantly whereas width of the lamina reduces from 6.2 to $1.9 \mathrm{~cm}$ from control $\left(\mathrm{T}_{0}\right)$ to maximum population level $\left(\mathrm{T}_{4}, 3000 \mathrm{~J}_{2} / \mathrm{kg}\right.$ soil). But among the treatments there was no significant difference between $\mathrm{T}_{0}, \mathrm{~T}_{1}$ and $\mathrm{T}_{3}, \mathrm{~T}_{4}$. The rate of multiplication was significantly reduced from 1.2 $\left(T_{1}\right)$ to $0.53\left(T_{4}\right)$ but there was no significant difference between $T_{1}$ and $T_{2}$ (Figure 1C).

\subsection{Beet-Root}

Table 5 (Figure 1D) reveals the development of root system of beet-root which was noted to be significantly reduced in plants receiving the highest $\left(3000 \mathrm{~J}_{2} / \mathrm{kg}\right.$ soil) population of nematodes per plant. Inhibition in growth of root resulted in formation of profuse knots in roots. Total weight of roots were observed to increase significantly from $27.2 \mathrm{gm}\left(\mathrm{T}_{0}\right.$ control) to $42.8 \mathrm{gm}$ at highest population level $\left(\mathrm{T}_{4} 3000 \mathrm{~J} / 2 \mathrm{~kg}\right.$ soil) whereas there was no significant difference between the treatments $T_{3}, T_{2}$ and $T_{1}, T_{0}$. However at $3000 J_{2}$ population level causes severe reduction in yield as well as quality in terms of deformed beet-root. The number of root-knots and root-knot index was significantly increased but the rate of multiplication was significantly reduced from $2.01\left(\mathrm{~T}_{1}\right)$ to $0.61\left(\mathrm{~T}_{4}\right)$ respectively over control but among the treatments $\mathrm{T}_{3}, \mathrm{~T}_{4}$ there was no significant difference (Plate D).

The rate of multiplication was found inversely proportional to the population density which gave conformity results in accordance with Seinhorst (1970). An increase rate of reproduction on above crops shows that these test crops are good host for root-knot nematode, M. incognita. Vovlas and Di Vito (1991) reported the relationship between initial and final population densities on coffee seedlings in a glasshouse experiment. Agwu and Ezigbo (2005), Anwar et al. (2007), El Sherif et al. (2007) and several other workers reported that root galls increased progressively and significantly with increased levels of inoculum.

\section{Conclusion}

An increase in nematode inoculums was associated with progressive reduction in plant growth parameters of both the test crops which gave conclusive evidence that $M$. incognita is potential pathogens for these crops. The rate of multiplication was inversely proportional to the population density which causes competition for nutrition among the developing nematodes within available root system and also due to inability of juveniles of subsequent generation to find infection sites.

\section{Acknowledgements}

Author is thankful to Professor Sobita Simon for constant help and moral support in conducting the experiments.

\section{References}

Anamika, Simon, S., Singh, K. P., \& Ghosh, G. (2011). Distribution of root knot nematode on major field crops in Uttar Pradesh (India). Archieves of Phytopathology and Plant Protection, 44(2), 191-197. http://dx.doi.org/10.1080/03235408.2010.505365

Anwar, S. A., McKenry, M. V., \& Javed, N. (2007). Development, reproduction, and root galling of Meloidogyne incognita populations on several cotton cultivars. Journal of Nematology, 39(1), 68.

Agwu, J. E., \& Ezigbo, J. C. (2005). Effect of M. incognita on the development of Abelmoschus esculentus (okra). Animal Research International, 2(3), 358-362.

Baum, T. J., Hiatt, A., Parrott, W. A., Pratt, L. H., \& Hussey, R. S. (1996). Expression in tobacco of a functional monoclonal antibody specific to stylet secretions of the root-knot nematode. Mol. Plant-Microbe Interact., 9, 382-387. http://dx.doi.org/10.1094/MPMI-9-0382

El-Sherif, A. G., Refaei, A. R., El-Nagar, M. E., \& Hagar, M. M. S. (2007). The role of eggs inoculum level of Meloidogyne incognita on their reproduction and host reaction. African Journal of Agricultural Research, 2(4), 159-163.

Hussey, R. S., \& Janssen, G. J. W. (2002). Root-knot nematodes: Meloidogyne species. In J. L. Starr, R. Cook \& J. Bridge (Eds.), Plant Resistance to Parasitic Nematodes (pp. 43-70). New York, USA: CABI. http://dx.doi.org/10.1079/9780851994666.0043

Hussey, R. S., \& Grundler, F. M. W. (1998). Nematode parasitism of plants. In R. N. Perry \& D. J. Wright (Eds.), The Physiology and Biochemistry of free-living and plant-parasitic nematodes (pp. 213-243). UK: CABI. 
Seinhorst, J. W. (1970). Dynamics of populations of plant-parasitic nematodes. Annu. Rev. Phytopathol., 8, 131-156. http://dx.doi.org/10.1146/annurev.py.08.090170.001023

Siddiqi, M. R. (2000). Tylenchida Parasites of Plants and Insects (2nd ed., p. 848). Wallingford, UK: CAB International. http://dx.doi.org/10.1079/9780851992020.0000

Singh, S., \& Goswami, B. K. (2000). Pathogenicity of Meloidogyne incognita on cowpea. Indian Journal of Nematology, 30, 249-250.

Sikora, R. A., \& Fernandez, E. (2005). Nematode parasites of Vegetables. Plant parasitic Nematode in subtropical and Tropical agriculture (pp. 319-392). CABI publishing, Wallingford, U. K. http://dx.doi.org/10.1079/9780851997278.0319

Kaskavalci, G. (2007). Effects of soil solarization and organic amendment treatments for controlling Meloidogyne incognita in tomato cultivars in Western Anatolia. Turk. J. Agric. For., 31, 159-167.

Vovlas, N., \& Vito M. D. (1991). Effect of root-knot nematodes M. incognita and M. javanica on the growth of coffee (Coffeaa rabica L.). Nematol. Medito, 19, 253-258.

\section{Copyrights}

Copyright for this article is retained by the author(s), with first publication rights granted to the journal.

This is an open-access article distributed under the terms and conditions of the Creative Commons Attribution license (http://creativecommons.org/licenses/by/3.0/). 